\title{
Money Management Behavior and Issues among Congolese University Students: Requirement for Educational Finance
}

\author{
Vigoureux Chinyabuuma ${ }^{1}$, Suprapto ${ }^{2 *}$, Muhammad Imron Romadhon ${ }^{3}$ \\ ${ }_{1,2,3}$ Universitas Negeri Yogyakarta, Indonesia \\ 'vigoufally@gmail.com, ${ }^{2}$ suprapto@uny.ac.id, ${ }^{3}$ imron.romadhon@gmail.com *corresponding author
}

\begin{abstract}
This study investigated the factors that influence a number of financial issues students face in the Democratic Republic of Congo. A survey was conducted to collect the data for this study. Respondents were asked to demonstrate which of the ten financial education topics they were keen on taking. Descriptive statistics was utilized to present the data. The results show that loans, residential status, and impulse spending were the causes that brought about the students' financial issues. By identifying the causes of students' financial issues, educators may be able offer a course, in which students can learn the money management skills needed to address these issues. The respondents were asked if they would be interested in financial education if offered. Almost all of the students expressed their interest in learning how to manage their money. In conclusion, many of the respondents did not have sufficient knowledge and skills in managing their financial affairs.
\end{abstract}

Keywords: financial issues, loans, residential status, impulse spending, money management

\section{Perilaku dan Masalah Pengelolaan Uang di Kalangan Mahasiswa Universitas Kongo: Kebutuhan Keuangan Pendidikan}

\begin{abstract}
Abstrak
Penelitian ini menyelidiki faktor-faktor yang mempengaruhi sejumlah masalah keuangan yang dihadapi siswa di Republik Demokratik Kongo. Sebuah survei dilakukan untuk mengumpulkan data untuk penelitian ini. Responden diminta untuk menunjukkan yang mana dari sepuluh topik pendidikan keuangan yang mereka minati. Statistik deskriptif digunakan untuk menyajikan data. Hasil penelitian menunjukkan bahwa pinjaman, status tempat tinggal, dan pengeluaran impulsif merupakan penyebab yang menimbulkan masalah keuangan siswa. Dengan mengidentifikasi penyebab masalah keuangan siswa, pendidik mungkin dapat menawarkan kursus, agar siswa dapat mempelajari keterampilan pengelolaan uang yang diperlukan untuk mengatasi masalah ini. Para responden ditanya apakah mereka akan tertarik dengan pendidikan keuangan jika ditawarkan. Hampir semua siswa menyatakan minatnya untuk mempelajari cara mengelola uang mereka. Kesimpulannya, banyak responden yang tidak memiliki pengetahuan dan keterampilan yang memadai dalam mengelola urusan keuangannya.
\end{abstract}

Kata Kunci: masalah keuangan, pinjaman, status tempat tinggal, pengeluaran impulsif, pengelolaan uang

\section{INTRODUCTION}

In the Democratic Republic of Congo, money management behavior is the primary issue requiring attentions in order to improve students' ability to effectively solve their financial issues in many universities. This condition is progressed by education services, including education loans and facilities since students have become one of the most important market segments in Congo. There are two conditional reasons with regard to this issue. The first one is the community with the financial capability to pay services or products using the 
availability of education loans. In this group, the convenience of education loans needs to be managed to address money management constraints among university students to encourage them to focus on their education. The second reason is the students' community that has the potential to earn more income than any other community groups in the society. It is hypothesized that understanding students' financial issues is very important to prepare them to manage their money during their studies.

It is a fact that not much is known about money management behavior and the financial issues faced by university students in Congo. However, creating an appropriate program can help students learn basic money management skills before they graduate and enter the workforce. A survey conducted in the United States shown that students experienced different financial socializations acted in different ways in certain parts of financial activities. Since financial education is not provided in schools, it can be assumed that students have poor knowledge about financial affairs. On the other hand, they are pressured to manage their money by themselves. It is very important for educators and researchers to understand money management behavior of university students, as they will become important consumers after they graduate. The knowledge of their behavior can encourage related agents to design appropriate learning programs to equip students with money management knowledge and the ability to help them act as effective personal financial managers in borderless and complicated financial markets.

Several studies related to money management behavior have been conducted by many scholars in the last decade. Lee (2015) discovered that adults' behavior, including money management behavior, was learned through socialization. Social learning and social interactions among buyers experienced by children in their cultures can be different. In this way, these shape the beliefs of the children and their behavior in surprising ways. Parents may be instrumental to show their children a balanced direction with regard to spending. Parents may also teach consumer skills when interacting with their children. In a previous study, it was found that parents influenced both financial and social motivation for consumption among young people (Ramadhana et al., 2019; Herawati et al., 2018), and the researchers summarized that children became much more independent and grew with more skills and knowledge. Students had twice as many credit cards, most of whom obtained their cards when they were 20 years old (Herawati et al., 2018). A similar study revealed that far more students, compared with non-students, mentioned that they had involved with unusual buying behaviors.

Better wellbeing allows parents to provide for their children. According to Lee (2015), parents may influence the increase in the materialistic orientation of their children. It is in accordance with Grusec's social learning model that explains that children usually learn by watching models (Grusec, 2019). Mothers are more likely to respect their children, ask their children's opinions, and often use certain messages to foster the improvement of decision-making capacity regarding consumption needed by their children (Meuleman et al., 2018). There is much more communication regarding money in the family of younger respondents than the older respondents, and there are far more mothers than fathers who inform them about financial matters. Herawati et al. (2018) and Mentari et al. (2019) found a 
conclusive association between the variables of family and the desire of impulsive spending behavior. Those interviewed for this survey used shopping to escape from their problems and to feel positive about themselves. Impulsive behavior is related to terrible childhood experiences such as parents' separation, death, lack of affection, suppression of feelings, high expectation, and punishments (Bensadon, 2015). The family background unquestionably affects the lives of impulsive spenders.

The money management behavior of students is learned in their social interactions. The adolescent's experiences and discoveries during their adolescence influence how they conduct themselves as adults. The data show that the higher the parental dependency level, the higher the subject's level of impulsive behavior (Mentari et al., 2019; Joo \& Grable, 2011). The increasing awareness of the need for university education creates an everincreasing number of individuals who are putting investment into higher education. According to Baum \& Schwartz (2015), the 1980 loans from government reserves granted to students increased by $59 \%$ in 1997 . From 2006 to 2014, the average parents' salary increased consistently by $10 \%$ while the cost of higher education increased by $91 \%$. However, the loans granted increased by only $48 \%$. Loans are the primary source of students' income, and $50 \%$ of them wish they had borrowed less while they are in university. Another study shows similar findings that the entire student debt has an impact when the students get married, have children, and buy a vehicle. Moreover, students are unable to estimate their whole debt.

Utilizing educational loans means incurring debt that university students have to pay back when they graduate. Unplanned financial affairs and an overextended loan can lead to a financial problem that is the inability to pay the debt. Eighty percent of the sample identified by Consumer Credit Counseling Services in Oregon and Washington were females. Females are more likely to be impulsive spenders (Müller et al., 2015).

University students in the United States borrow more, work less, and complete their studies with more debt (Baum \& Schwartz, 2015). However, Kahn \& Lespinasse (2020) compared the proportion of real debts with perceived burdens, and it was concluded that if the payment of debt is $7 \%$ of the total net income, about $25 \%$ of the borrowers would feel burdened. De Gayardon et al., (2019) also found that the majority of respondents had expected the degree of difficulty of repayments they encountered. Meanwhile, $75 \%$ of the respondents indicated that their career decisions were not influenced by their debts.

Furthermore, some studies revealed that students need more information about certain knowledge of borrowing (Schwartz \& Bleemer, 2019; Krabbe, 2020; Mackenzie, 2020; Johnson et al., 2016). According to Adzis et al., (2017), 42\% of students did not have any clue when their repayment will start, $37 \%$ of them did not have any knowledge of the interest rate on their loans, and almost $25 \%$ of the others did not have any idea of the duration of their lending grace period. The results show that there was a critical relationship among student loan knowledge, gender, marital status, residency status, and date of borrowing. The individuals who first borrowed before 1983 appeared to have lower scores in knowledge, while married people and in-state residents had higher knowledge score. 
Most students get loans because the money is needed to pay for their studies. Studies conducted in the United States have found that many students who took advantage of loans for their educational purposes had limited knowledge about the various aspects of their loans, their ability to cope with loan repayments, and how increasing debts affect different parts of their lives. The majority of the studies mentioned above focused on credit usage while none of them focused on financial issues and requirements that students faced. For this reason, this study focused on money management behavior, the causes of students' financial problems, and this study also discussed the requirements for financial education. Hypothesis 1: The following variables are used to forecast successful financial conduct and greater financial issues: gender, ethnicity, place of origin, parent's marital status, and educational level, family income, childhood consumer experience, birth order, type of college, residence, education fund, financial socialization, grade point average (GPA), spending patterns, savings, and financial literacy.

Hypothesis 2: Financial awareness should have a positive impact on successful behavior. Those with bigger financial issues would show low financial literacy rates. Those reporting bigger financial problems will report low levels of financial literacy.

\section{METHOD}

A self-administered survey was utilized to collect the data in this study. The respondents were 1500 students receiving educational student loans from one public university in Congo. The data were collected within three weeks from the $1^{\text {st }}$ to the $21^{\text {st }}$ of December 2019. The data presented in this paper are a part of a larger study on money management behavior among university students. The variables used in this survey were 13 items put on a Likert scale in the forms of statements that described money management behavior and a list of 16 finance-related experiences/issues (Adzis et al., 2017).

In addition, the respondents were asked to demonstrate which of the ten financial education topics they were keen on taking. Marital status, gender, number of siblings, origin place, education achievement, whether or not the respondents experienced staying at a boarding school, the marital status of parents, educational accomplishment, and occupation were the money-related variables tested. Descriptive statistics were utilized to present the data.

\section{FINDING AND DISCUSSION}

The description of the 1500 respondents who took part in this study is illustrated in Table 1. Forty percent of them were males, and the rest (60\%) were females. More than $70 \%$ of the respondents were the Kinoise followed by the Katangaise, the Kivusien, and others. The Kinoise are the people from the capital of the Democratic Republic of Congo; the Katangaise are people from Katanga Province, and the Kivusien are people from the Eastern part of the country. Respondents were asked to show where they came from such as rural area/village, small city, urban area (city or town). The largest proportion of the respondents (56\%) came from rural areas, and $44 \%$ of them came from urban areas. Those raised in urban areas might have been more exposed to goods and services than those raised 
in rural areas. On the contrary, when entering university, those from rural areas may have expected to look toward substantial changes in their spending environment.

To help themselves, $14 \%$ of respondents relied only on educational loans. Other forms of financial assistance came from one to eight sources. A third of the respondents received the majority of their money from their fathers. Less than $40 \%$ of the respondents received money from their mothers. It is presumably because more than half of the respondent's mothers were full-time housewives. The source of money affected the respondents' buying power and had impacts on the financial problems they faced. The total amount of money the respondents earned was US\$ 71 equivalent to 121,356.48 FC (Franc Congolais), with males earning marginally more (US\$ 77 or 131,640.41 FC) than females (US\$ 67 or $114,519.49$ FC). Students from the Katangaise group earned marginally more than others.

Table 1. Profile of the Respondent by Gender

\begin{tabular}{llcccc}
\hline & & \multicolumn{2}{c}{ Male } & \multicolumn{2}{c}{ Female } \\
\cline { 3 - 6 } Ethnicity & & $\mathbf{N}$ & $\mathbf{\%}$ & $\mathbf{N}$ & $\mathbf{\%}$ \\
& Kinoise & 413 & 70.5 & 656 & 73.1 \\
& Katangaise & 116 & 19.8 & 151 & 16.8 \\
& Kivusien & 37 & 6.3 & 53 & 5.9 \\
& Other & 20 & 3.4 & 37 & 4.1 \\
\hline Birth Order & Only Child & 6 & 1.0 & 9 & 1.0 \\
& Youngest & 109 & 18.5 & 160 & 17.7 \\
& Middle & 303 & 51.4 & 486 & 53.8 \\
& Eldest & 172 & 29.2 & 248 & 27.5 \\
\hline Origin Place & City & 197 & 33.4 & 287 & 31.9 \\
& Small City & 118 & 20.0 & 191 & 21.2 \\
& Village & 275 & 46.6 & 422 & 46.9 \\
\hline College Boarding & Yes & 311 & 52.8 & 398 & 43.7 \\
& No & 279 & 47.3 & 509 & 56.1 \\
\hline School GPA & $<2$ & 35 & 6.0 & 38 & 4.4 \\
& $2-2.49$ & 160 & 27.5 & 210 & 24.1 \\
& $2.5-2.99$ & 206 & 35.4 & 329 & 37.8 \\
& $3-3.74$ & 161 & 27.7 & 262 & 30.1 \\
& $3.75-4$ & 20 & 3.4 & 31 & 3.6 \\
\hline
\end{tabular}

$N^{*}=$ Represents the total number of individuals

\section{Family Foundation}

Family foundations have an impact on the social experience and financial assets that students have access to (Sabri \& MacDonald, 2010). The respondents were asked to indicate the academic achievements of their parents, and more than $70 \%$ of respondents gave appropriate responses. Among the individuals who responded to this inquiry, $44 \%$ of them indicated that their mothers had substantially less education and that their fathers had somewhat higher education as most of them had a Congolese diploma education or higher. Most of the respondents' mothers were housewives. On the other hand, most of their fathers had the best possible occupation. About $10 \%$ of the students' fathers had retired. 
The respondents' parents' income is shown in Figure 1 with various backgrounds. Sixteen percent of respondents did not answer questions about their parents' income; $67 \%$ of them reported one source of income, and $17 \%$ reported the income of both parents. Parents' salaries have an impact on the size of the money received by the respondents. Respondents from the dual-career families mentioned that they received money from their mothers and fathers. The month to month standard amount of money received from their parents was US\$ $40(67,440.00 \mathrm{FC})$ with male earning more (US\$ 43) than female (US\$34). Those from dual-career families reported that their parents earned a normal salary of US\$ 63 (106,218.00 FC), compared to only US\$ 43 (72,498.00 FC) among the families with only one working parent.

\section{Money Management Behavior}

Thirteen elements were linked to the questionnaire to measure the respondents' money management behavior. Respondents were approached to show whether they agreed or not with each statement that described their money management behavior. Figure 2 reveals the number of respondents who approved of the statement by gender.

Overall, the general picture shows that the majority of the respondents (males and females) agreed that they spent their money recreation and fun. Conversely, more female respondents reported that they would, in general, enjoy shopping and buying goods at favorable prices. More male respondents indicated that they hid the way they managed the money given by their parents. The male respondents revealed that their obligations were creating problems. This information showed that there were respondents who tended to be involved with impulse buying practices and sales promotion that strongly influenced some of them.

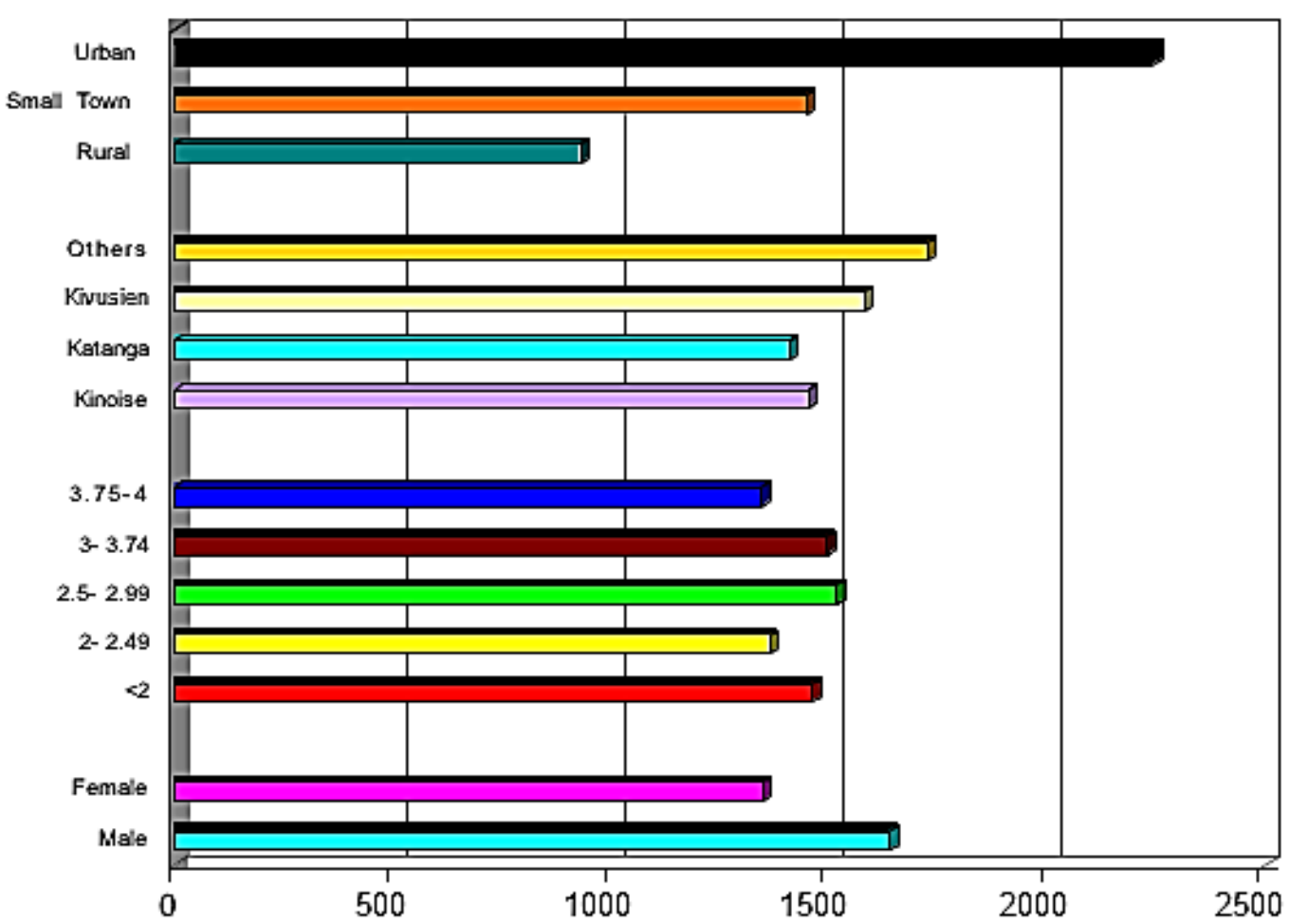

Figure 1. Mean Family Income by Gender, College GPA, Ethnicity, and Place of Origin 


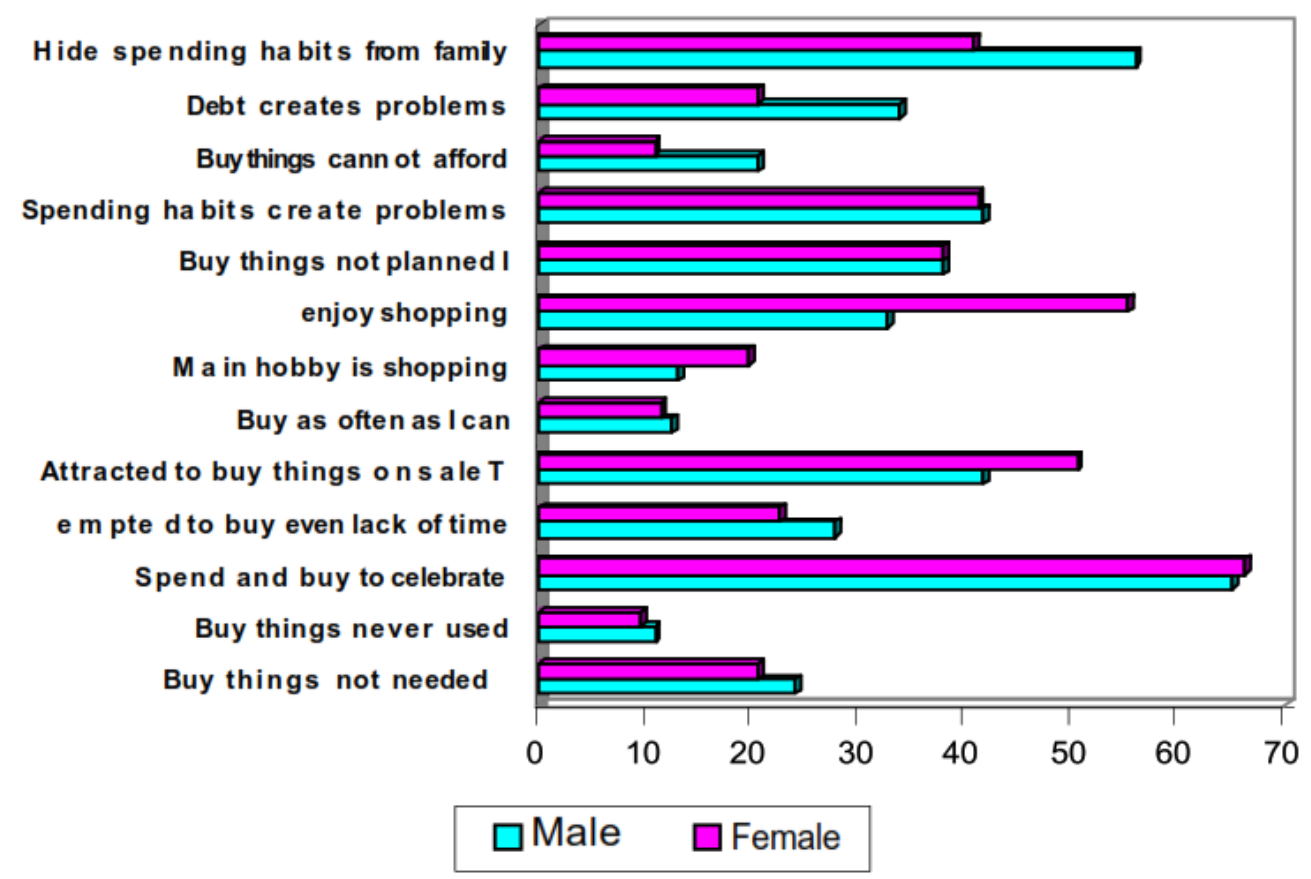

Figure 2. Respondents' Percentage Agreeing with "Gender"

\section{Financial Issues}

The inability to manage money resources can create a couple of problems. Since the respondents lived by themselves, their ability to manage their money had an impact on this research. The expansion of the buyer's market and presentation exercises, such as sales promotions and offers, make it more challenging for people to adapt to growing market's interests for their money (Saidi, 2018). The data from this study show the knowledge of the financial issues and pressures faced by the students. The issues recorded came from a rundown utilized by the Financial Directing Facility at Kinshasa University to determine the type of money management guide required of students in seeking financial advisory services. In Figure 3, it can be seen that the number of respondents who revealed that they had experienced problems was recorded based on their gender. A higher rate of males compared to females who encountered specific problems was recorded. A more significant share of all respondents announced skipping dinner to spare money. The respondents who lived off-campus usually ate instant noodles to save their money.

When the starting point is considered, the higher number of the respondents from the rural areas encountered more problems in contrast with those from urban areas; the students from the rural areas may have had limited resources compared to those from the urban areas. More than a third (35.1\%) of those from rural areas indicated that financial issues affected their thinking compared to only $23 \%$ from urban areas reporting this. Sixty percent of the respondents from rural areas skipped their dinners in order to save money while only $46.1 \%$ of those from urban areas did this.

The students' residential status can also cause a problem. The large number of students living off-campus did not have enough money to continue their studies until the end of the semester. However, this did not seem to be the case for those living on campus. 
Students living off-campus spent more money on things that students living on campus do not have to buy such as car fuel. On the other hand, more students living on campus skipped their dinners to save money. Since their money is not enough to continue their studies until the end of the semester, some students had to borrow money from their friends. Nearly a third $(30.5 \%)$ of the male respondents indicated that they intended to pay their debt when they received the borrowed money.

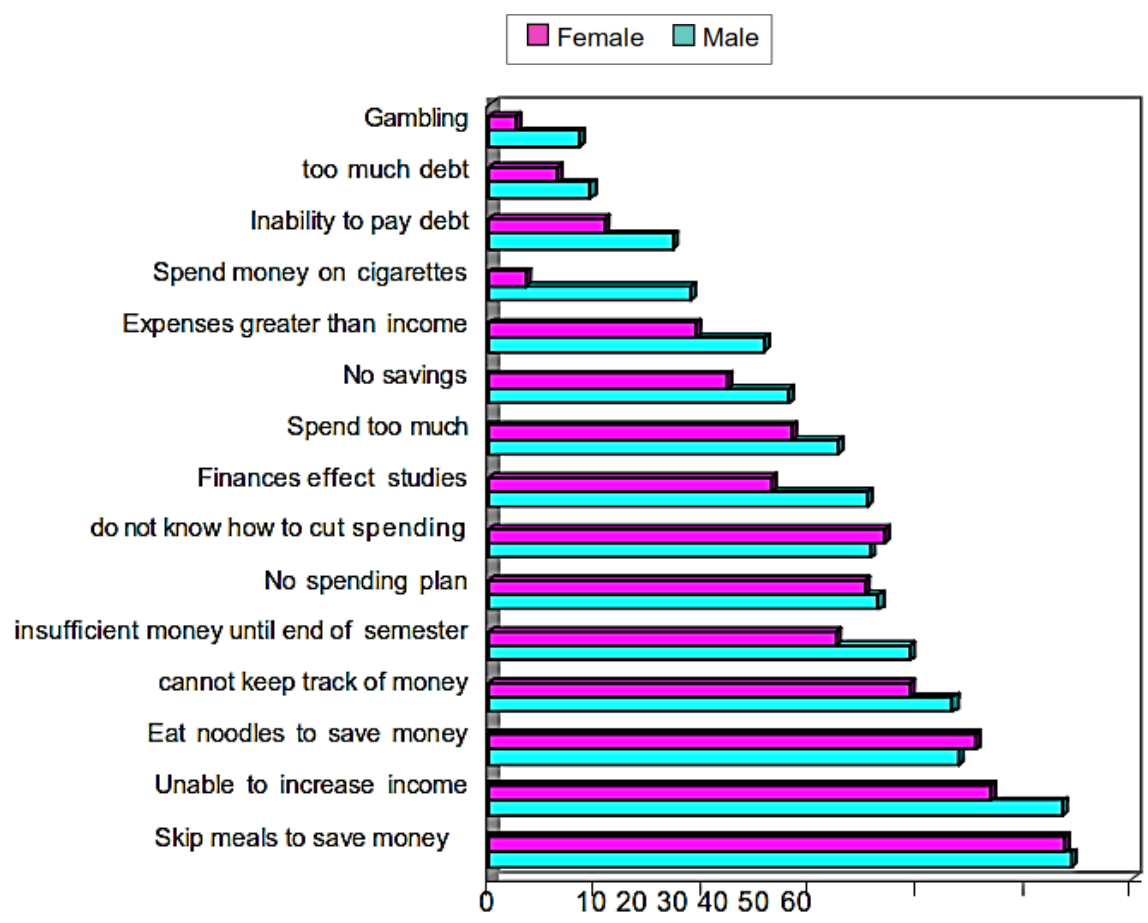

Figure 3. Financial Issues by Gender

Figure 3 shows the number of common problems found by gender, college grade point average, and ethnicity. In total, 43 males (7.3\%) and 77 (8.5\%) females swore they had never experienced the 16 problems listed. When the problem faced by the respondents was verified, it seemed that the unnecessary problems encountered by the female respondents were different from those faced by the male respondents. The most important information was that the female respondents reported they had experienced one to four problems while the male respondents revealed they had encountered more than three problems.

The problems university students faced were significantly different when their academic accomplishments were analyzed. Those with higher grade point averages reported fewer problems than those with lower GPAs. In this way, the lack of financial management skills can also be seen through the absence of academic management skills. Ethnicity also made a significant difference in financial matters. The Kasai and Goma ethnic groups (shown in Figure 4 by "Others") are at the top of the list followed by The Kinoise. Students from the Kasai and Goma ethnic groups experienced more financial difficulties because the demand for money was higher for them, and the loan amount they got was similar to that of the Kinshasa loan. 


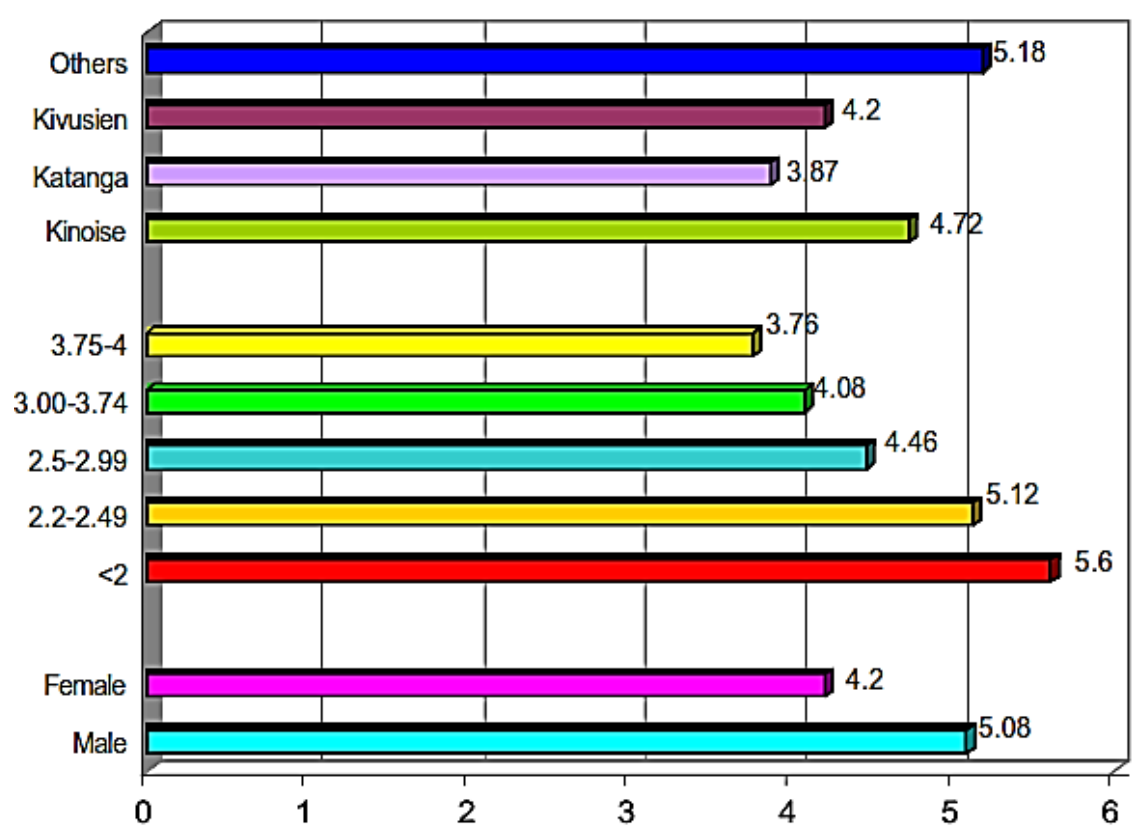

Figure 4. Financial Issues Experienced by Ethnicity, GPA, and Gender

\section{Financial Education Needs}

The explanation presented above indicates that the respondents did not have the essential skills to handle their financial resources. The results of this study are similar to a previous study (Yahaya et al., 2019). The respondents were approached to indicate whether they needed assistance on how to best deal with their money management issues. Most of the data $(90 \%)$ revealed that they were interested in learning about money management.

Figure 5 shows the number of the respondents who were interested in learning about specific topics. The highest number of the respondents expressed that they wanted to have counseling administration by learning about saving and investment, planning, how to increase their salaries, and money management. More than $50 \%$ of the respondents revealed that they might want to learn about private management, how to reduce expenses, protection guarantee, and smart spending.

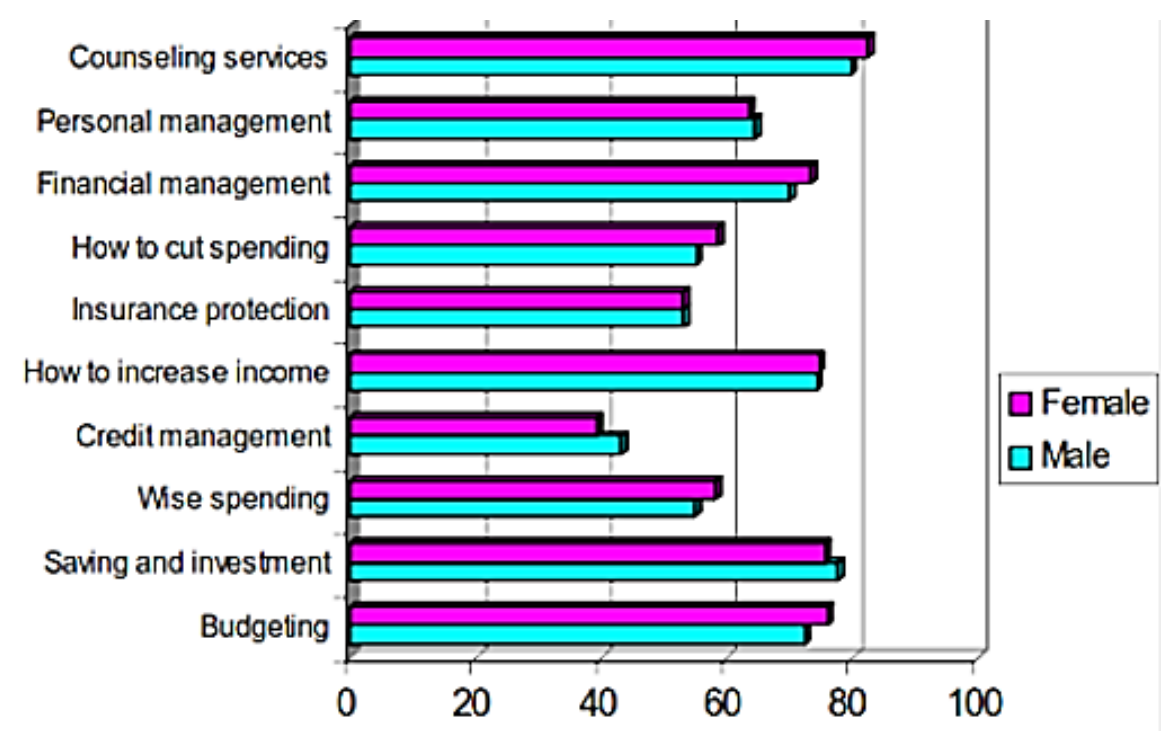

Figure 5. Respondents' percentage desiring education funding service by Gender 


\section{CONCLUSION}

This study revealed the factors that had influenced the financial issues the university students faced in the Democratic Republic of Congo. These factors are related to educational loans in Congo. The first factor was the respondents who took out such loans and did not have other sources of income. The second factor was the respondents who came from the rural areas. Students from rural areas had limited resources compared to those from the urban areas. Furthermore, a higher number of students living off-campus who did not have enough money to continue their study until the end of the semester had different problems compared with those living on-campus. Students living off-campus spent more on things that students living on-campus did not have to pay for such as car fuel. The third factor is impulse spending; the overall picture showed the majority of the respondents agreed that they spent and bought things for recreation and fun. Therefore, these made them spend more money on things they do not need. The data showed that some respondents tended to be involved with impulse spending and sales promotion that greatly influenced some of them. By looking at these factors, it can be argued that these students lacked money management skills. The development of the financial market expects consumers to have knowledge and skills to select services they need. Giving essential money management knowledge and skills before the students enter the market will be helpful. In other words, they will be prepared with essential skills to deal with their finance. The data revealed that the respondents did not get adequate knowledge and skills to resolve their money management problems. Financial education should be given at school to prepare students to manage their finance.

\section{REFERENCES}

Adzis, A. A., Bakar, J. A., \& Shahar, H. K. (2017). Factors influencing young adults' debt in Malaysia. Journal of Business and Retail Management Research, 12(1), 76-85. https://doi.org/10.24052/jbrmr/v12is01/fiyadim

Baum, S., \& Schwartz, S. (2015). Student aid, student behavior, and educational attainment. Decision Making for Student Success: Behavioral Insights to Improve College Access and Persistence, January 2015, 38-60.

Bensadon, B. A. (2015). Attitudes, Beliefs, and Behavior. In Psychology and Geriatrics: Integrated Care for an Aging Population (pp. 45-67). Elsevier Inc. https://doi.org/10.1016/B978-0-12-420123-1.00003-4

de Gayardon, A., Callender, C., \& Green, F. (2019). The determinants of student loan takeup in England. Higher Education. https://doi.org/10.1007/s10734-019-00381-9

Grusec, J. E. (2019). Social Learning Theory. In Reference Module in Neuroscience and Biobehavioral Psychology. Elsevier. https://doi.org/10.1016/B978-0-12-8093245.23568-2

Herawati, N. T., Candiasa, I. M., Yadnyana, I. K., \& Suharsono, N. (2018). Factors That Influence Financial Behavior Among Accounting Students in Bali. International Journal 
of Business Administration, 9(3), 30. https://doi.org/10.5430/ijba.v9n3p30

Johnson, C. L., O’Neill, B., Worthy, S. L., Lown, J. M., \& Bowen, C. F. (2016). What Are Student Loan Borrowers Thinking? Insights From Focus Groups on College Selection and Student Loan Decision Making. Journal of Financial Counseling and Planning, 27(2), 184-198. https://doi.org/10.1891/1052-3073.27.2.184

Joo, S. H., \& Grable, J. E. (2011). An exploratory framework of the determinants of financial satisfaction. Journal of Family and Economic Issues, 25(1), 25-50. https://doi.org/10.1023/B:JEEI.0000016722.37994.9f

Kahn, M. J., \& Lespinasse, M. (2020). Managing Student Debt. In The Business Basics of Building and Managing a Healthcare Practice (pp. 69-73). Springer International Publishing. https://doi.org/10.1007/978-3-030-27776-5_11

Krabbe, M. S. (2020). The price of higher education: Experiences of american student loan borrowers. In Research in Economic Anthropology (Vol. 40, pp. 109-123). Emerald Group Publishing Ltd. https://doi.org/10.1108/S0190-128120200000040008

Lee, H.-S. (2015). The Differences of the Characteristics of Adolescent Consumers' Socialization According to Growth Stages. Journal of Consumer Policy Studies, 46(2), 133-163. https://doi.org/10.15723/jcps.46.2.201508.133

Mackenzie, L. (2020). A Case of Capability Expansion or Capability Reduction? An Exploration of Loan Recipients' Views of ICETEX: Colombia's Higher Education Student Loans Institute. Journal of Hispanic Higher Education. https://doi.org/10.1177/1538192720920071

Mentari, N. W., Setiawina, I. N. D., Budhi, I. M. K. S., \& Sudirman, I. W. (2019). Influence factor of consumers interest on using E-money. International Journal of Social Sciences and Humanities, 3(2), 176-186. https://doi.org/10.29332/ijssh.v3n2.311

Meuleman, R., Lubbers, M., \& Verkuyten, M. (2018). Parental socialization and the consumption of domestic films, books and music. Journal of Consumer Culture, 18(1), 103-130. https://doi.org/10.1177/1469540516648372

Müller, A., Mitchell, J. E., \& De Zwaan, M. (2015). Compulsive buying. American Journal on Addictions, 24(2), 132-137. https://doi.org/10.1111/ajad.12111

Ramadhana, M. R., Karsidi, R., Utari, P., \& Kartono, D. T. (2019). Role of Family Communications in Adolescent Personal and Social Identity. Journal of Family Sciences, 4(1), 1-11. https://doi.org/10.29244/jfs.4.1.1-11

Sabri, M. F., \& MacDonald, M. (2010). Savings Behavior and Financial Problems among College Students: The Role of Financial Literacy in Malaysia | Sabri | Cross-cultural Communication. Crosscultural Communication, 6(3), P103-110. https://doi.org/10.3968/j.ccc.1923670020100603.009

Saidi, N. A. (2018). Determinants Of Financial Problems Among Adults. January.

Schwartz, A., \& Bleemer, Z. (2019). Precautionary Student Borrowing: Hometown Unemployment and Student Loans. SSRN Electronic Journal. 
https://doi.org/10.2139/ssrn.3414499

Yahaya, R., Zainol, Z., Abidin, J. H. O. @ Z., \& Ismail, R. (2019). The Effect of Financial Knowledge and Financial Attitudes on Financial Behavior among University Students. International Journal of Academic Research in Business and Social Sciences, 9(8), 22-32. https://doi.org/10.6007/ijarbss/v9-i8/6205 